\title{
ARTICLES
}

\section{ALTERNATIVE VISIONS OF SECURITY IN NORTHEAST ASIA}

\section{Sheldon W. Simon}

Although no security structure exists yet in Northeast Asia comparable to Europe's NATO, there is movement toward new arrangements as the century ends. Unresolved cold war disputes on the Korean Peninsula and between China and Taiwan as well as controversy over an appropriate Japanese role in the twenty-first century combine to sustain general regional support for a continued American force presence in Japan and Korea. Nevertheless, two potential developments could erode that presence over time: (1) the unification of Korea, after which U.S. troops on the peninsula might be unacceptable and (2) a change in American budgetary priorities that could significantly draw down forward deployments in the western Pacific. In anticipation of these changes, Northeast Asian states are beginning regional security dialogues.

We may now be experiencing one of those relatively rare periods in world affairs where the structure of the international system does not dominate foreign policies. While the old cold war alliances have not completely disappeared from U.S. security policy, their ability to determine reflexively America's foreign relations on issues from Bosnia in Europe to the Spratly islands in the Pacific has greatly atrophied. For other states, too, domestic considerations and nearby regional concerns take precedence over alliances with remote great powers whose reliability is problematic in this new era. To better understand this unfamiliar international security environment, analysts should concentrate on internally generated alternative national visions of security that, in the aggregate, are creating a new, innovative structure of international politics.

\section{ASIA-PACIFIC SECURITY SITUATION}

Since this article deals with visions of Asia-Pacific security, perhaps the best way to begin is to ask, how realistic is the concept of a Pacific Community? At bottom, in a post-cold war setting, hopes for such a community are based on the optimistic belief that positive social, economic, political, and military linkages among Asia-Pacific states will create a sufficiently large 
number of benefits that conflicts among these states will invariably be resolved peacefully. Yet, many centrifugal forces operate against the Pacific Community concept. Global economic integration, epitomized by the World Trade Organization (WTO), and global pressures for democratization are examples of pressure from above; from below, subregional economic and financial networks such as the South China growth zone encompassing Fujian, Hong Kong, and Taiwan as well as local security dynamics may be supplanting the American balancing role. Moreover, as Robert Manning and Paula Stern argue: "To begin the process of turning the [Asia-Pacific] region into a community, its two giants, China and Japan, will have to work out their relationship's formidable security problems, just as France and Germany did 40 years ago."

Europe is catching up with North America in its relations with the Pacific rim. By 1992, the Europeans had already begun to trade more with Asia than with the United States ( $\$ 249$ billion to $\$ 206$ billion); and the book value of the EU's direct foreign investment in Asia now roughly equals that of the United States. In fact, the trade pattern of most East Asian economies is equally distributed among the United States, Europe, and intra-Asian trade with the last growing markedly faster than the other two. ${ }^{2}$ This dispersion of Asia-Pacific economic relations can only loosen trans-Pacific ties over time.

Finally, many Asian states are distancing themselves from American pressures with respect to democratization and human rights, emphasizing instead the differences between Western and Asian cultures and stages of development. Both considerations place economic and social rights ahead of individual rights. Moreover, Asian spokesmen, such as Singapore's senior minister, Lee Kwan Yew, reject lectures coming from Americans whose country leads the world in murder rates, per capita incarceration, and gun ownership. U.S. efforts to inject labor and environmental rights into international economic negotiations are seen as self-serving protectionism rather than sincere human rights concerns. To several East Asian leaderships, then, the United States is seen to be as much a problem as a solution for regional security. While the American military presence remains welcome for the promotion of regional stability, Washington's pressures on human rights, democracy, and labor standards are perceived as threats to domestic stability in states where regimes have not yet worked out their own new relationships between governments and societies. ${ }^{3}$ The notion of liberal governance, which provides a space for societal autonomy is less accepted in much of Asia. Because the state is privileged over society in the region, American efforts to stress the latter's legitimacy are seen as domestic political interference.

External security architectures are also moving in a new direction as the millennium approaches. In a region where there are no declared adversaries (with the exception of the Korean Peninsula), multilateral efforts are on the rise as a means for promoting security with rather than against states. ${ }^{4} \mathrm{New}$ 
fora have been created at both the nongovernmental Track II level (The Council on Security Cooperation in the Asia-Pacific-CSCAP) and at the official level (The ASEAN Regional Forum-ARF) to provide early warnings of impending security conflicts and to offer suggestions for coping or resolving them short of combat. An integral part of this process entails a search for confidence building, reassurance, and transparency measures among states that may confront each other over territorial, boundary, resource, refugee, smuggling, drug, and piracy issues. Track II discussions permit officials in their "private capacities" to test proposals and raise issues that may be too sensitive to address in formal government negotiations.

Nevertheless, older arrangements have not been jettisoned. Indeed, some have even been enhanced. Thus, at ASEAN's fourth summit in 1992, Association leaders took an expansionary view of security by explicitly adding the topic to ASEAN's agenda with its dialogue partners, including the United States, Japan, and China. Northeast Asia, too, is moving tentatively toward new security linkages. Although there is still no Northeast Asian security forum as a counterpart to the ARF, South Korea is urging its creation. What may be the first Northeast Asian security collaborative effort is found in the Korean Peninsula Energy Development Organization (KEDO), whose primary members are the ROK, Japan, and the United States. KEDO is responsible for funding and building light water nuclear reactors in North Korea to replace the more weapons-grade plutonium-prone graphite reactors built by the Russians. This project, whose ostensible purpose is to provide electrical energy for the DPRK, also has an important security dimension. It has brought Pyongyang's weapons grade plutonium production to a halt and resuscitated the International Atomic Energy Agency's inspection program of North Korean reactors. If peace on the Korean Peninsula is Northeast Asia's most important security problem, then the multilateral KEDO is providing support parallel to the bilateral ROK-U.S. Security Treaty.

\section{U.S. FOREIGN POLICY VALUES}

Since national security policies appear to be driven by domestic dynamics in the post-cold war, assessing contending schools of thought in the Clinton administration and its congressional antagonists should help us understand underlying U.S. foreign policy values. As we shall see, this clash of values may account for the apparent incoherence in U.S. policy toward the AsiaPacific region. ${ }^{5}$ Four competing value sets can be identified in contemporary American foreign policy. For any particular issue, one or more may dominate the others. In the aggregate, however, they seem to create a series of actions that move in contradictory directions. Three of these sets coexist within the Clinton administration-neo-Wilsonianism, economic nationalism, and strategic realism. The fourth-minimalism-is found in the Republican-dominated Congress. 
Neo-Wilsonianism represents the thinking of both the president and his national security advisor, Anthony Lake. It is based on the belief that modern democracies are essentially peaceful trading states that, at least in the twentieth century, have not fought one another. Committed to their peoples' prosperity and well being, prospects for a peaceful world in the post-cold war period will be enhanced as democracy expands. Therefore, U.S. foreign policy should urge other states to create the conditions for democratic governance. Neo-Wilsonians are also committed to multilateral institutions as instruments of diplomacy, particularly within the United Nations system. The UN and other multilateral fora permit the United States to remain involved in the world at a reduced cost through burden sharing. Multilateral arrangements also reduce the probability of unilateralism, which has been a primary source of instability in recent times. The Clinton administration believes that the United States can promote democracy in this new era because it need no longer back authoritarian regimes simply because they are anticommunist. Multilateralism promotes security through reassurance and confidence building rather than balances of power.

Coexisting with neo-Wilsonianism in the Clinton administration is economic nationalism. Best represented by the late secretary of commerce, Ron Brown, and the U.S. trade representative, Mickey Kantor, the economic nationalists have emerged from the president's belief that domestic political success depends upon the creation of jobs within the U.S. economy. Promoting exports creates American jobs. Therefore, a major goal of U.S. foreign policy is to open foreign markets by breaking their trade barriers. Thus, the United States has been willing to risk other strategic and political interests in pressing long-time partners, such as Japan and South Korea as well as important regional powers such as China, to make room for U.S. exports, protect U.S. intellectual property rights, and cease "unfair subsidation" of their own domestic industries or face consequent American trade sanctions. Economic nationalism, although partially successful in opening some markets, for example, semiconductors in Japan, risks alienating long-term friends and degenerating into renewed protectionism if sanctions are widely invoked. Moreover, the unilateralism inherent in this approach undermines the new more comprehensive multilateral trade liberalization found in the WTO. Paradoxically, because the United States is a founding member of the WTO, Washington's policy of economic nationalism also undermines the more consensual global economic order that the WTO seeks to create.

The third school of security thought in the Clinton administration has carried through all American presidencies since World War II. Strategic realists are currently found primarily among the foreign policy and defense professionals in the Departments of State and Defense. They emphasize the importance of sustaining U.S. cold war bilateral relationships and forward deployed forces in both Europe and Asia as a kind of general deterrence 
against any rising powers that may be contemplating the use of force to alter the territorial status quo. They argue that peace is best sustained through power balances and that in the post-cold war era, a U.S. political, economic, and military presence in the Asia-Pacific region provides the stable environment needed for the kinds of political and economic changes advocated by the preceding foreign policy schools. Indicative of strategic realism is the February 1995 Department of Defense Report, U.S. Security Strategy for the East-Asia-Pacific Region. It promises to retain 100,000 forward deployed forces in East Asia so that America will continue to be a stabilizing factor in the region. It also promises to sustain bilateral alliances as the framework for that deployment, while simultaneously nurturing multilateral relationships to complement the U.S. presence. Finally, the report reaffirms the importance of the U.S.-Japan Security Treaty as the linchpin for continued regional security. Implicitly the United States and Japan together insure that no other state can attain hegemony. As a former senior official at the Japan Defense Agency puts it:

If Japan and the PRC were to form an alliance relationship, other countries would believe that a terrible threat had appeared. Conversely, if Japan formed an alliance with the island countries, the PRC would regard it as an alliance encircling it. ${ }^{6}$

Although U.S. forward deployment advocated by the strategic realist school is generally welcomed throughout Asia as a guarantee of a continued American commitment, its reliability is questioned. Because of the budgetdriven downsizing of U.S. forces, there is a general belief that the United States sees few issues in the Asia-Pacific region worth the risk of American lives and resources. Contention over ownership of the Spratly Islands, boundary and resource disputes among neighbors, or possibly even a PRC threat to Taiwan are not seen as events that would automatically elicit a U.S. military response. At bottom, regional specialists question the relevance of the U.S. military for most Asian security conflicts in the post-cold war. ${ }^{7}$

Nevertheless, the United States seized the opportunity presented by PLA missile tests and combined arms exercises in the Taiwan straits this past March. Designed by the PRC to intimidate Taiwan voters during the country's presidential election, Washington responded by deploying two carrier groups to the region, ostensibly to monitor the exercises-a normal Seventh Fleet activity in a calmer political environment. In this highly charged context, however, the Seventh Fleet action sent messages not only to China and Taiwan but equally important to the Asia-Pacific region generally: that the United States was still prepared to insert its armed forces into potentially destabilizing situations to deter the use of force. The American action was, in fact, fairly low risk. The PLA possesses neither the intention nor the capability of invading Taiwan at this point in time. Indeed, China was engaged in 
coercive diplomacy, not a prelude to war. However, had the United States not responded to China's display of force, regional apprehensions about America's willingness to continue as an Asia-Pacific power balancer would have been exacerbated and U.S. political stature would have further eroded. For the time being, at least, American credibility as an Asia-Pacific security contributor has improved.

Finally, minimalism challenges all of the preceding approaches to U.S. foreign/security policy. Epitomized in the Congress by Senators Phil Gramm and Jesse Helms as well as House Speaker Newt Gingrich, and outside Congress by former presidential hopefuls Pat Buchanan and Ross Perot, minimalists are characterized by leadership and compassion fatigue. They argue that the United States has borne the burden of world leadership since 1945. With the cold war's end, there is no need to continue. Let the world's ills be treated by those countries most directly affected. Multilateral organizations, such as the United Nations or, for that matter, regional and bilateral alliances, are also suspect for they entangle the United States in the problems of far-off lands. The minimalists, then, plan to reduce U.S. overseas commitments and withdraw forward deployed American forces. They have a kind of late nineteenth century view of world politics in which the United States can best prosper outside the mainstream of world affairs. However, there is an important difference between the minimalists and classic U.S. isolationists: the minimalists advocate a large American defense budget. U.S. armed forces would not be committed to multilateral organizations, however. Rather, they would be structured for unilateral intervention if America's vital interests were threatened anywhere on the globe. Fortunately, the minimalists remain a distinct minority in elected office. However, they are sufficiently powerful that both the neo-Wilsonians and strategic realists must consider their objections whenever the use of American forces is contemplated.

At best, then, U.S. strategy in the Asia-Pacific region-with the exception of the Korean Peninsula-is one of calculated ambiguity. Secretary of Defense Perry has stated (Beijing, October 1994) that the peaceful settlement of contending Spratly claims is exceedingly important because military action there could upset regional stability and threaten the sea lines of communication (SLOCs). The U.S. Navy is committed to keeping the SLOCs open; therefore, Perry's statement could be interpreted as an implicit warning to the PRC about tolerable limits to its actions in the South China Sea. Nevertheless, offshore American forces are no tripwire as demonstrated by China's construction of communications facilities at Mischief Reef, adjacent to the Philippines. The building of more such structures by the PRC would constitute a creeping assertiveness against which the Seventh Fleet is not a serious obstacle. 


\section{CHINA'S STRATEGIC VISION}

The most difficult time in any authoritarian state's foreign/security policy is during a period of political transition when contenders for leadership search for important institutional backers (in the PRC, the PLA) to consolidate control and create legitimacy for their authority. During transitional periods, leaders may adopt particularly hard lines toward adversaries to demonstrate leadership strength and, therefore, ability to uphold the national interest.

For the PRC, major foreign policy goals have remained consistent since the late 1970s: first, to achieve national prosperity through export-led growth and foreign investment, while simultaneously protecting the communist party's dominant political position from being undermined by "bourgeois values," which enter China with the influx of foreigners and the economy's integration into the global capitalist system.

Since Tiananmen Square (1989), the party's opposition to domestic political liberalization has reached extremely high levels. However, the party also understands that its only claim to authority rests on the country's continued high economic growth so that the population can foresee the prospect of increasing living standards despite the leadership's authoritarianism. To smooth the way for trade and foreign investment, PRC leaders insist that a tranquil environment and peace with all their neighbors have the highest priority.

China's second goal is, however, somewhat contradictory to the first; and here is where trouble in China's foreign policy arises. The second goal is the reunification of all territory claimed by Beijing. This nationalist goal-possibly a substitute for the collapse of Marxist ideology as a unifying forceimmediately brings China into territorial conflict with several neighbors. While Taiwan is the primary target, there are also significant disputes with Japan (the Senkaku islands) and all the ASEAN states because of PRC ownership claims to the whole of the South China Sea and all of the island groups within it.

The more China emphasizes the second of these two goals, the more the first is in jeopardy, particularly because Taiwanese investors fear their commercial holdings on the mainland could become hostage to nationalist ends. If China chooses to use force to achieve any of its unification claims, trade and investment could be devastated through embargoes and capital flight with unforeseen consequences for China's domestic political stability.

From these contending foreign policy goals emerge two schools of thought about China's foreign/security policy future. Either could be correct. Each could be right within two different time frames. The first school argues that the leadership will continue on the path of foreign investment-led growth and encourage a stable regional environment. All Asia-Pacific states support this 
policy. Underlying its validity is the belief that, despite its very impressive aggregate economic growth, the PRC will remain a poor country (in per capita income) well into the next century. Consequently, China's leaders will have to focus on feeding, clothing, sheltering, and educating its population. Territorial expansion, in this scenario, at best will be quietly dropped or, at worst, indefinitely postponed.

The second school of thought sometimes acknowledges that the first school's assessment may be accurate for the next five to ten years. Subsequently, however, as China modernizes, if the nationalists prevail, it will aspire to regional hegemony by moving to occupy Taiwan and the Spratly Islands. To forestall these developments, Asia-Pacific states agree that the PRC must be integrated into a regional political-economic-security framework. In effect, China's neighbors wish to buttress the China of the coastal, commercial south against the nationalist party, PLA, bureaucracy of the north and the PRC's interior.

For now, the U.S. General Accounting Office assessment of the PLA seems reassuring. It notes that modernization is proceeding very gradually from a base of 1950s and 1960s equipment. Since effective power projection requires command, control, and communications capacities as well as an extensive logistics train, the PLA remains years behind. Thus, the United States views the PLA missile tests near Taiwan as little more than crude efforts at political intimidation and not a prelude to invasion. To place China's military modernization in context, its acquisition of twenty-four SU27 fighters gives the PLA a roughly equivalent modern air combat capability to that of Malaysia, which is acquiring eighteen Mig-29s and six F-18s.

Moreover, Chinese leaders understand that the communist party's continued control depends on its ability to sustain the country's economic growth via trade and foreign investment. A China that creates a larger space for societal activity in commercial affairs and private life does not necessarily lead to democracy, however. PRC leaders insist that rapid social change requires a strong government to maintain domestic order. In opposition to those advocating democracy, defenders of the regime note that "an anarchical China would [pose] a genuine threat to the outside world."8 The most serious threat to China's security, then, is not an external military challenge (there are none) but Western schemes to promote "peaceful evolution," a code phrase to subvert CPC leadership by political and cultural infiltration designed ultimately to make China a Western dependency. Furthermore, Chinese officials interpret Taiwan's efforts to play a larger global role and Hong Kong Governor Chris Patten's plan to democratize Hong Kong as elements in a hidden Western agenda to keep China divided and subject to Western interference. ${ }^{9}$

This suspicion of Western goals carries over into regional security discussions. While China is a member of the ARF-the Asia-Pacific's first pan- 
regional security discussion organization-Beijing is intent on limiting any interference by the ARF in China's military development. The PRC is particularly reticent about publicizing the PLA's doctrine and order of battle to accommodate ARF transparency requests, implying that such demands are really thinly disguised quests for intelligence. ${ }^{10}$ When China finally did release its first White Paper on Arms Control and Disarmament, it was essentially a restatement of its well publicized arguments that the PRC constituted a threat to no one, that its military budget was minimal, that its forces were being reduced, that it behaved responsibly in transferring military hardware to other countries, and that it actively promoted arms control and disarmament. There was not discussion, however, of the capabilities and role of China's new air and naval platforms or of the PLA's long-term weapons development plans and how they relate to its overall strategy. The U.S. Department of Defense believes that the PLA is probably fifteen years away from developing a modern sustainable force projection capability with command and control, aerial refueling, and possibly an aircraft carrier. ${ }^{\text {" }}$ Needless to say, these prospects were not discussed in China's White Paper.

\section{TAIWAN'S FUTURE AND REGIONAL SECURITY}

As long as an unreformed, authoritarian Kuomintang (KMT) governed the island of Taiwan, its future relationship to mainland China could be postponed well into the twenty-first century. PRC officials stated in the early 1980s that their country's economic growth would bring the mainland abreast of Taiwan within about fifty years. By that time, a new political relationship could be forged because the standards of living of the two polities would be equalized. Thus, the question of whether Taipei or Beijing was the legitimate government of the whole of China could be finessed through two to three leadership generations on both sides of the Taiwan Strait.

Ironically, from the perspective of the Clinton administration, which has emphasized the desirability of democratization for global peace, the recent liberalization of Taiwanese politics and the legitimation of political parties committed to the island republic's independence have created a potential crisis in PRC-ROC relations. In effect a new political identity is being created in Taiwan based not on ethnicity but rather political participation. With the presidential election in March 1996, both the executive and the legislature are now democratically constituted and can, therefore, claim legitimacy-a condition notably absent on the mainland. Although Taiwan authorities have been careful not to forecast independence, the elections are interpreted by PRC leaders as the first step in that direction-a step that must be resisted.

To a certain extent, economic ties across the strait could ameliorate political tensions. The PRC has strongly encouraged Taiwanese trade and investment in the mainland. By 1994, the PRC accounted for 16 percent of 
Taiwan's total trade, a figure worrisome to island officials since anything over 10 percent is considered dangerous dependence. ${ }^{12}$ On the other hand, insofar as PRC prosperity is dependent on commerce with Taiwan, the probability of a military option for unification should be reduced. Moreover, Taiwan is more than a simple trade partner. It is a conduit for overseas Chinese capital through joint ventures as well as a source of technology transfer that permits the PRC to upgrade its economy. Given the uncertainty of Hong Kong's role after 1997, Taiwan's importance to China's prosperity can only grow.

Beijing acknowledges Taiwan's economic strength by agreeing to the latter's membership in international economic organizations such as APEC and ultimately - following China's own admission-the WTO. However, the PRC opposes Taipei's participation in any body devoted to security discussions such as the ARF, since membership would imply the island's recognition as a political entity. Moreover, China does not want to be placed in a setting where Taiwan could raise bilateral security issues for other AsiaPacific states to debate. ${ }^{13}$

During fall 1995 interviews in both the PRC and Taiwan, the author found specialists on both sides concerned with developing some new way to continue peaceful coexistence that takes into account the political changes in Taiwan. Without a new relationship, both economies could be harmed. China could lose its most important external investor, and PRC military threats could destroy confidence in Taiwan's future. The PLA missile tests off the Taiwan coast in July 1995 led to a precipitous drop in the Taipei stock market. These same missile tests also caused Taiwan's pro-independence party to back away from its insistence on complete separation from the mainland. The even more provocative March 1996 missile tests within twenty miles of Taiwan's two largest ports demonstrated that Beijing could disrupt the island's international trade and negatively impact its stock market again. The PRC is particularly incensed at Taiwan's efforts to secure a seat in the United Nations, though it is a fruitless endeavor. No major country supports Taipei's application and, if necessary, Beijing could veto it.

Taiwanese researchers have discussed two models for future relations with their PRC counterparts. ${ }^{14}$ One is based on the Finland-USSR relationship in which the former guaranteed the latter that it would not ally with any country and thus could not pose a threat. The acceptability of this model to Beijing is slim, however, since it is premised on Taiwan's independence. A second model would construct a confederation between the two entities. Each side would retain political autonomy; but independence would be ruled out. In this model, the two sides could move closer together over time-particularly if liberal political changes occurred on the mainland and its economy continued to prosper. This model is an application of the PRC's early 1980s idea that over several decades the PRC and ROC would gradually come together. 
However, it is also based on assumptions of political liberalization and continued high economic performance as well as a cap on the rise of militant nationalism for both sides.

The democratization of Taiwan also possesses positive security implications. Other democratic states, led particularly by the U.S. Congress, have become committed to the island's political survival because its government now reflects the will of the electorate. It would be difficult for Washington and other democratic governments to sit by idly if Taiwan were blockaded or invaded. Taiwan continues to rely on the U.S. Seventh Fleet's deterrent effect, especially since the navy has been very clear that any interference with the freedom of international commerce would be viewed as a serious threat to regional security. Meanwhile, Taiwanese Track II groups work hard to be included in regional security discussions where they can engage their PRC counterparts and other regional members. Taiwanese think tanks are meeting annually with the Malaysian and Philippine ISIS and with a Northeast Asia Security discussion forum jointly sponsored by the New York Asia Society and the Japan Institute of International Affairs. ${ }^{15}$

In sum, unless cooler heads prevail in both Chinese capitals, Beijing and Taipei could be on a collision course. The PRC believes Taiwan to be following a course of "creeping independence" by raising its international profile, seeking a seat in the United Nations, serving as a major trade and investment partner for Southeast Asia, and legitimating its new national identity through free elections. The Chinese Communist party has held no such legitimating procedure for its rule. PRC leaders may have concluded, therefore, that time is no longer on their side. To delay a political showdown with Taipei may risk losing the unrecovered territory. Hence, the communist party's Leading Group on Taiwan Affairs recently ruled that a "covert independence movement" by itself constitutes sufficient grounds for an invasion even without a formal declaration of independence. Concurrent with this declaration the PLA has created a "Nanjing War Zone" covering the Taiwan Strait, with the authority to call upon units from neighboring regions. ${ }^{16}$

In effect the PRC is following a strategy of coercive diplomacy toward Taiwan, combining threatening statements, military deployments, missile firing, and invasion exercises to influence the island's elections and ultimately force it to negotiate with Beijing on the future political relationship. These pressures are sufficiently alarming that Japan, despite its own domestic political disarray, used some of its strongest postwar diplomatic language in talks with China, insisting that the latter settle its differences with Taiwan peacefully. ${ }^{17}$ Continuation of this downward spiral need not be inevitable. Conciliatory gestures have been made by both Taipei and Beijing in the presidential election's aftermath. Compromise must come from both capitals. Time is not on Taiwan's side in an atmosphere of confrontation, however. The PLA will only get stronger; and prolonged tension in the strait will drain Taiwan's 
economy. An atmosphere of reconciliation, on the other hand, would benefit both sides. Over the decades, if China stays on a free market track, Taiwan can play an important facilitative role. Unification can be postponed in this setting to future generations. At bottom, Taiwanese authorities must somehow reassure their mainland counterparts that the island's de jure political independence is not part of the KMT agenda.

\section{U.S.-JAPAN/ U.S.-KOREA SECURITY RELATIONSHIPS}

Although Japan's domestic political malaise and protracted trade conflict with Washington cloud the overall relationship between these two economic superpowers, virtually all regional observers continue to perceive the U.S.Japan nexus as a linchpin for regional security. Indeed, the overall AsianPacific interest in the maintenance of U.S.-Japan defense ties may be out of sync with bilateral developments between Tokyo and Washington. Budget cutbacks in both capitals are reducing military deployments. Also, the end of the cold war has led attentive publics in both countries to question the necessity of having 47,000 U.S. troops stationed in Japan.

Yet, there is little doubt that the U.S. security treaties with both Japan and the ROK will be sustained well into the coming century. Because Japan, unlike Germany, has not successfully assured its neighbors that it has genuinely repented its 1930 s-1940s militarism, and because Japan needs to convince these same neighbors that its economic strength will not be translated into independent military power, the U.S.-Japan treaty constitutes a kind of guarantee that Japan will not resume its old ways. ${ }^{18}$ Indeed, even the socialists under Prime Minister Murayama reversed their long postwar anti-U.S. treaty policy to embrace the LDP commitment as well as U.S. forces on Japanese soil.

Should the Security Treaty be tested, however, with, for example, a crisis on the Korean Peninsula requiring an American military response, the U.S.Japan tie could be severely strained. Washington and American public opinion would expect direct Japanese military support. If that support was not forthcoming under the prevailing interpretation of Article IX of Japan's Constitution, the U.S.-Japan alliance might well collapse. Moreover, Washington might even impose trade sanctions against a Japan that stood by while a neighbor crucial to Japan's security was being defended by the United States alone. ${ }^{19}$ Finally, another issue that Washington and Tokyo must discuss is whether the treaty's scope will be expanded beyond East Asia, say, to the Persian Gulf. Japanese officials are reticent about endorsing such an expansion of responsibilities that would imply the permanence of U.S. bases in Japan. ${ }^{20}$ For example, Diego Garcia is completely dependent on support from Japan. Without the Japanese bases, the U.S. ability to sustain a permanent presence in the whole Asia-Pacific-Indian Ocean region would be greatly 
eroded. Yet, if Japan is to continue to provide these facilities indefinitely, Tokyo should become a more equal partner in determining how and when these forces would be used. A more equal security partnership, however, would also entail a revision of Article IX. Under the article's current interpretation, areas beyond East Asia appear to be excluded.

The April 1996 visit by President Clinton to Tokyo has opened a new stage in the two countries' security relations. Japan has agreed to conduct a review of the conditions in which cooperation with the United States would be appropriate for regional security and stability. This could be the first step toward joint operations via logistical support for U.S. forces during crisis situations in East Asia or further afield. The new access and cross servicing agreement provides for peacetime logistical aid, thus giving the armed forces of the two countries some joint operations experience that could in the future be applied in crises from Korea to the Persian Gulf if Japan's interpretation of Article 9 were to change.

While much of Asia would accept expanded U.S.-Japan security cooperation related to the maintenance of an American air and naval presence in East Asia, this is not the case for China. Indeed, references in the U.S.-Japan joint statement implicitly refer to the PRC when delineating as regional problems "nuclear arsenals, potential regional conflicts, unresolved territorial disputes, and the proliferation of weapons of mass destruction as well as their means of delivery."

Not surprisingly, China has responded apprehensively to the joint U.S.Japan statement. PRC media claim that the Japan-U.S. alliance is now "directed at the Asia-Pacific as a whole" and that Japan is now a part of America's global military strategy. What's more, China suspects that any redefinition of U.S.-Japan strategy is aimed at the PRC. Nevertheless, Beijing still sees value in the U.S.Japan arrangement for it keeps a cap on Japan's rearmament.

Another prominent issue is the creation of a new, independent role for the JSDF (Joint Self-Defense Force) through United Nations peacekeeping activities. After its tentative and not completely successful participation in the UNTAC Cambodian force, Japan has subsequently sent JSDF personnel to Africa and the Middle East. In addition to signifying Tokyo's commitment to global peace, this more pro-active policy toward UN collective security is forcing Japan to confront Article IX's prohibition of collective security and consider either an amendment to the constitution or, at least, a more flexible interpretation of the article. Japan's second largest party-the New Frontier composed of younger ex-LDP reformers-goes even further by arguing that Japan should evolve toward a "normal state" with regular commitments to UN security activities. The United States would welcome this development. However, the PKO Law would require extensive revision if these changes are to occur. 
Currently, the law prohibits the SDF from participating in peace enforcement activities. It also requires new Diet approval for any new SDF action related to peacekeeping, including monitoring ceasefire agreements, troop withdrawals, and buffer zone patrols. Japanese public opinion polls show that while there is considerable support for JSDF humanitarian actions through medical aid and infrastructure repair in war torn countries, that consensus evaporates when the SDF might be put in harms way by monitoring opposing sides in a conflict. ${ }^{21}$

Nevertheless, recent official advisory commissions to the Japanese government have recommended a larger role for the JSDF in joint exercises with U.S. forces and a revision of the Self-Defense Force Law to provide for participation in UN peacekeeping. Additionally, Japan's sponsorship of multilateral institutions such as APEC and the ARF are means of "softening the dominance of U.S.-Japan relations." 22 Multilateralism helps to restore Japan's legitimacy and is a way of responding to Asian criticism about the country's self-absorption.

If the Japan-U.S. security relationship is the linchpin for the American forward presence in East Asia, the ROK-U.S. defense treaty constitutes the commitment for which most U.S. forces in the region are prepared. For Northeast Asian states, avoiding war on the Korean Peninsula and helping Pyongyang survive its current economic implosion are high priorities. Security specialists agree that the alternatives could be devastating to Asian stability: either a costly war with high casualties and severe strains in Japan-U.S., China-U.S., and ROK-China relations or a precipitous collapse of the North Korean regime accompanied by massive population movements to the South that Seoul is prepared to handle neither politically nor economically.

A PRC analyst noted that Beijing is introducing North Korean specialists to China's southern Special Economic Zones (SEZs) and encouraging the DPRK to be more receptive to foreign capital. China is also recommending that the North seek better relations with its southern neighbor, Japan, and the United States-all of which could provide the capital and aid Pyongyang needs to rebuild its economy. Overcoming North Korea's history of autarchy (chuche), however, will be a slow process. Also, it is best that outsiders use carrots, not sticks, to achieve these changes.

For South Korea, the two key players in dealing with the North are the United States and China. The former provides the deterrent, while the latter serves as an interlocutor, urging the North Koreans to effect a rapprochement with the ROK. Nevertheless, strains are apparent in the ROK-U.S. relationship. Some South Korean officials resent what they see as the secondary role assigned their government in negotiating the nuclear power equipment agreement with the North, particularly since the South will bear most of the costs of building the $\$ 4$ billion light water reactors in the DPRK. ${ }^{23}$ South Korea is concerned that the United States will construct a separate relationship with 
Pyongyang, ignoring Seoul's advice. Therefore, the South Korean government is interested in creating a multilateral security forum for Northeast Asia that would guarantee Seoul's involvement in all regional security discussions.

Overriding the ROK-U.S. security relationship are the political-security implications of the peninsula's unification either through a gradual process of change in North Korea or Pyongyang's precipitous implosion. If a peaceful Korean unification is achieved, the raison d'etre for American forces in that country disappears. Moreover, once U.S. forces leave Korea, the Japanese public will also question the necessity for American forces in Japan. After all, their primary rationale currently is to deter and, if necessary, repel a North Korean invasion of the ROK. While a persuasive rationale for U.S. Navy bases (and perhaps an Air Force contingent) can be devised in terms of western Pacific SLOC protection and as a regional balancer, there would be no justification for U.S. ground forces, including marines, in Northeast Asia. This further reduction in forward deployed American military forces would undoubtedly provide an impetus for the development of a new, unified Korea's regional power projection capability in order to protect the country's trade routes and promote its territorial claim against Japan with respect to the Tokto/Takeshima islands. In sum, in the absence of regional arms control arrangements, Korea's unification, the withdrawal of American forces from the peninsula, and their subsequent reduction in Japan, would probably accelerate a Korean air and naval power projection buildup and possibly similar countervailing developments in Japan and China. Interestingly, a high-ranking North Korean military officer told Selig Harrison that this is precisely the reason why North Korea no longer insists on an American exit from the Korean peninsula. Any U.S. withdrawal from Korea, it is feared, would precipitate Japan's rearmament. ${ }^{24}$

\section{RUSSIA AS A MINOR PLAYER}

Russia's role in post-cold war East Asian security is a mere shadow of its Soviet predecessors. Where once Moscow was the primary backer of Vietnam's occupation of Cambodia and the dominant underwriter of North Korea's economy as well as the home of the region's second most powerful naval force, now its minimal economic and military presence scarcely register on the region's political radar screen. Although Russian leaders still consider their country to be an Asian power, with two-thirds of its territory east of the Urals, in fact, Moscow's practical ability to affect regional developments is hardly visible. Indeed, it would not be amiss to say that Russia does not have an Asian security policy. Rather, it promotes an Asian commercial policy with sales of advanced weapons to China (SU-27s, SAMs, and armor), the ROK (some armor so that the ROK army can exercise against elements in the North Korean inventory), and Malaysia (Mig-29s). Because Moscow con- 
centrates its foreign policy attention almost entirely on the "near abroad," even its own Far East has been ignored and left to its own devices.

Russia has been excluded from involvement in solutions to the North Korean nuclear issue. Although the KEDO has expanded to include ASEAN and Western Europe, Russia is not involved. Russian diplomats are eager to participate in a Northeast Asian security dialogue if one is created; but the Russian Far East's lack of appeal to East Asian investors continues to undermine Moscow's hopes for a larger political role. Siberia's adamant opposition to the return of the northern islands to Japan precludes large-scale Japanese investment in the Russian Far East. In essence, that issue is stalemated.

Even the relationship with the ROK that began so well under Gorbachev has faded in recent years because of Russia's economic decline. In 1995, trade volume had stalled at around $\$ 3$ billion, well below the projected $\$ 10$ billion. And the ROK has invested less than $\$ 30$ million. ${ }^{25}$

In time, Russia will recover from its economic and political turmoil and demand its proper role in East Asian affairs. It would be wiser to open the door to regional dialogue so that Moscow can bring its influence to bear in a positive manner rather than shut it out until the time comes when it may see itself in an adversarial position. This point is illustrated by Russia's insulted reaction to the Clinton-Kim May 1996 proposal for four-way talks to replace the 1953 Korean armistice agreement. While the United States and ROK proposal includes only the original armistice signatories (plus the ROK) because they are directly affected by any new arrangement, Russia believes that its exclusion displays contempt for its diminished political status. ${ }^{26}$

\section{CONCLUSION: THE DEVELOPMENT OF MULTILATERAL REGIONAL SECURITY}

The essence of external security in the post-cold war Asia-Pacific is the quest for a concert arrangement through which states might be able to offset threats perceived to emanate from one another by adopting policies of reassurance, transparency, and confidence-building. ${ }^{27}$ Most Asia-Pacific states, via such groups as APEC and the ARF, are attempting to create a sense of community, institutions, and practices-sufficiently strong and widespreadto elicit expectations of peaceful change. While the security dilemma is not completely overcome by members of this "community," they, at least, believe that all-out war will not occur among themselves as a means of conflict resolution. To achieve this end, small states within this community will support principles of nonintervention and/or the promise of assistance from other members. Some may still desire to keep defense pacts with larger states, usually to deter regional powers. Indeed, regional norms of nonintervention, preventive diplomacy, and confidence-building comprise the strategies of small states vis-à-vis their more powerful neighbors. However, these coop- 
erative communities cannot form successfully if a potentially deviant state is bent on seeking relative gains at others' expense.

Without publicly identifying an Asian regional threat, a hidden consensus seems to be forming centered on China's future capabilities and intentions. Indeed, Beijing's regular refutations about a "China threat" are designed to defuse these concerns, but to little avail. The PRC's long-standing claims to the Spratly Islands and all their surrounding seas plus Beijing's more recent military action across the Taiwan Strait have created a powerful impression that China is the only major unsatisfied power in the Asia-Pacific region. Compared to this, unresolved border demarcations and conflicting claims to small islands pale in significance.

The region's members have abjured any strategy of confrontation with China, however. Instead, they are following an inclusive approach to the PRC, welcoming its membership in regional groups and urging transparency, confidence-building, and multilateral negotiations upon Beijing. Concern about China has also worked in favor of maintaining external security ties to the United States as a hedge. Washington could expand these arrangements by building on existing multilateral activities such as the Rim of the Pacific (RIMPAC) exercises to involve more Asian participants. Through RIMPAC, for example, the United States can facilitate new patterns of naval cooperation between South Korea and Japan. RIMPAC might also be useful as a way of involving the Russian Pacific fleet in multilateral exercises and possibly even elements of the PLA Navy if the PRC is willing to experiment with multilateral cooperation. In the absence of arms control arrangements for Northeast Asia, a modest level of joint military exercising could, at least, enhance transparency.

Joint exercises in Northeast Asia might also serve as a device to begin to break down secrecy. Information exchange among armed forces is a particularly important Confidence-Building Measure (CBM), leading to both transparency and reassurance. If countries exercise together, then they should be able to ask questions and expect answers about systems capabilities and doctrines for their use.

Before assessing the prospects for a multilateral or cooperative security forum in Northeast Asia, an important caveat should be acknowledged. Unlike Southeast Asia where a regional political organization (ASEAN) has been in existence for about twenty years and where the region's major security challenge is, indeed, multilateral (ownership of the Spratly Islands and their surrounding waters), in Northeast Asia, the major security problems remain predominantly bilateral (North and South Korea; China and Taiwan; China and Russia; and Russia and Japan). Most claimants are wary of outside involvement, particularly if that involvement entails restrictions on the deployment of armed forces. ${ }^{28}$ China and North Korea have long opposed a multilateral security approach. Even in the KEDO, North Korea acts as if the 
multilateral nuclear energy program is strictly a bilateral U.S.-DPRK concern, minimizing the roles of the ROK and Japan. It would be very difficult, therefore, to transfer Northeast Asia's two most intractable conflicts-the Korean Peninsula and the Taiwan Strait-to a multilateral venue.

Having said that, multilateral arrangements may still be useful to states hoping to contain conflicts and demonstrate that their intentions are defensive/protective. Hypothetically, if a Northeast Asian security forum were to focus on the Korean Peninsula, it might begin at the low level of information exchange by both sides to enhance transparency. ${ }^{29} \mathrm{~A}$ forum might subsequently provide opportunities for each side to raise questions concerning information provided by the other. These initial two stages of the forum are probably sufficiently difficult to remain its only Korea-oriented activities for some time. Should the antagonists agree to proceed from there, a third task would be the development of norms to promote a degree of disengagement along the 38th parallel, notification of exercises, exchanges of observers, and explanations for any new arms buildups and deployments. An international forum, acceptable to both sides, could render objective assessments of the forgoing and make its findings available to both Koreas and the international community. The basic problem is, of course, obtaining Pyongyang's agreement. For example, the DPRK has not responded affirmatively to requests for dialogue by the Track II CSCAP, informally explaining that the DPRK trusts none of its potential dialogue partners to discuss the Korean Peninsula: the ROK, Japan, and the United States are antagonists; Russia has turned on North Korea; and China is unreliable. This deeply ingrained suspicion of all other actors does not augur well for Korean CBMs. ${ }^{30}$

A variety of regional security views, interpretations, and policy preferences was expressed to the author by Asia-Pacific specialists in the autumn of 1995. These views ranged from a strong endorsement for multilateral fora to considerable suspicion about their purposes and efficacy. It would certainly be fair to say that no consensus has yet emerged. A discussion of these views with an emphasis on Northeast Asia concludes this article.

Respondents throughout the Asia-Pacific region identified China as their major long-term external security concern, but none advocated confrontation. All believed the best approach to China was engagement politically and economically, bilaterally as well as through regional organizations. PRC respondents demurred, by contrast, over the proliferation of multilateral security venues in the Asia-Pacific region. Ji Guoxing of the Shanghai Institute of International Studies supported the idea of unilateral transparency through the independent publication of White Papers. (China is reportedly going to produce such a document for the first time in 1996.) He sees a progression toward confidence-building that goes from White Papers and military personnel exchanges to military doctrine discussions, and ultimately arms control and institution-building. Ji believes that territorial disputes should be sepa- 
rated from CBMs so that the former do not obstruct progress on the latter. ${ }^{31}$

In many ways, the ARF's creation was a logical extension of ASEANbased security discussions, which had gone on for over a decade, that is, since Vietnam's Cambodian intervention in late 1978. By initiating AsiaPacificwide security dialogue, ASEAN hoped to reassert the association's primacy after APEC had been "captured" by the United States and Japan. The ASEAN states wanted to insure there was no repetition of this experience in security matters. With ASEAN at ARF's core, presumably the "Asian way" would dominate regional security, that is, dialogue rather than the creation of binding legal arrangements. ARF was also seen by both ASEAN and Tokyo as a device to involve Japan in regional security without threatening its neighbors. Indeed, Japan has taken the lead in funding and directing a kind of secretariat for ARF on CBMs between the forum's annual meetings. ARF also provides, of course, an opportunity to engage China.

Indeed, ARF's most prominent "success" in its short existence grew out of China engagement at the July 1995 Brunei meeting. ASEAN members pressed China on negotiations over the Spratly Islands at a time when Beijing feared diplomatic isolation in the region. Relations with the United States and Japan were tense because of human rights concerns, nuclear testing, and PRC military efforts to intimidate Taiwan during its elections through missile tests over the Taiwan Strait. In this highly charged atmosphere, Beijing did not want to alienate ASEAN as well over the Spratlys, so at least a rhetorical concession was made. The ASEAN states interpreted that concession as a possible breakthrough, though, in fact, little subsequent follow-up has occurred. China agreed for the first time in Brunei to engage in multilateral negotiations on the Spratlys with other claimants and to consider the 1982 Law of the Sea (LOS) as the basis for these negotiations. The significance of the latter is that the 1982 LOS provides that all littoral states with overlapping territorial waters and EEZs should negotiate out their overlapping jurisdictions. According to ASEAN analysts, this meant that China had implicitly accepted the legitimacy of others' claims on the Spratlys-a substantive change from its earlier rejection of their holdings as invalid because of PRC sovereignty over all the South China Sea. ${ }^{32}$ The Brunei "breakthrough" on the South China Sea disputes would not have occurred had ARF not been in place and, therefore, China had not been pressured to negotiate. Interestingly, the LOS principle of overlapping territorial jurisdictions could also extend to PRC-Japan conflicting claims with respect to the Senkaku/Diaoyutai Islands and ROK-Japan claims to the Takeshima/Tokdo islets.

A major reason for Taiwan's keen desire for membership in the ARF is also to use the forum for internationalizing the cross-strait dispute with the PRC. Taiwan-based analysts believe that a regional security framework in which both Taipei and Beijing hold membership would block the PRC's military assertiveness. After all, a PLA attack on Taiwan would threaten 
freedom of the SLOCs and potentially destabilize the whole region by interfering with trade and undermining investment. Beijing perceives possible Taiwanese membership in ARF in exactly the same fashion and, therefore, adamantly opposes it. China insists that its actions toward Taiwan are an internal matter, which brook no international interference. Moreover, Taiwan cannot be permitted to enter the ARF because the latter is explicitly devoted to security; and only sovereign states can be members of international security groups. To admit Taiwan would be to accept the prospect of its sovereignty.

At the very least, Taiwan is lobbying for membership in the Track II CSCAP. However, even in that body, Beijing has raised strong objections. In hopes of effecting a compromise, the U.S. delegation at the June 1995 CSCAP International Steering Committee tabled an amendment to the CSCAP Charter that provides for a new category of "Observer/Affiliate." This category was established specifically to provide a vehicle for Taiwan's informal participation. While the new category of "membership" has been approved by CSCAP, Taiwan has not yet been invited to participate because the PRC continues to raise objections even in Track II fora. ${ }^{33}$

In summary, for the smaller states of the Asia-Pacific region, the ARF is a way of keeping big powers inside a collaborative organization where they might be required to explain and justify their security policies toward the region. In a sense, ASEAN respondents to the author's interviews saw the ARF as a means for extending ASEAN's successful experience in preventive diplomacy to the whole Asia-Pacific. Yet ASEAN members do not want the $\mathrm{ARF}$ to move into transparency and CBMs too quickly. There is a fear that this would spook China. Thus, ASEAN's original idea for the ARF to establish a regional security studies center was dropped at the July 1994 Bangkok meeting because it was considered to be a device for mandating transparency. The region as a whole does not yet seem ready for this step because to some, particularly China, transparency requirements equate to intelligence gathering.

What role, then, for the future of multilateralism? In general, the AsiaPacific preference is informality and an expansion of existing arrangements rather than the imposition of new ones. Expanding existing maritime cooperation efforts might be a good place to begin, building on the old US.-Soviet or recent Russia-Japan Incidents at Sea Agreements and broadened to include. other countries as well as a safety-at-sea dimension. A similar expansion of anti-piracy cooperation beyond the current Strait of Malacca arrangement to the China Seas seems feasible. Signatories could also add pollution control and search and rescue operations. ${ }^{34}$

Buttressing these multilateral arrangements, however, for the foreseeable future, should be the maintenance of forward deployed U.S. forces. They balance North Korea and China and render Japan's own growing military 
capability acceptable to the rest of the region. It would be unwise, however, to go beyond defense arrangements among neighbors by attempting to create a multilateral security community for the Asia-Pacific region at this time. No real community consisting of common values, interlocking histories, and the free movement of peoples and firms across national boundaries exists yet. Hence, the reticence about creating political institutions that would entail policymaking based on legal procedures. Successful institutions require common views of objectives as well as cost and benefit sharing. ${ }^{35}$

Trust and confidence can be achieved even if a security community is not created, however. CSCAP recommendations to the ARF for greater transparency on military doctrine, capabilities, and intentions could provide the reassurance necessary to insure that military modernization does not escalate into arms races. Toward this end, uniform outlines to provide comparability for defense policy white papers, arms registries, and defense expenditures would be most helpful.

Finally, Asia-Pacific states must understand that in the current U.S. political climate, overseas security commitments may not be sustainable if it appears that U.S. forces are protecting the external security of countries that have become long-term creditors of the United States and that appear to keep their markets closed to American products. In the post-cold war period, American foreign policy in the Asia-Pacific is driven primarily by commercial considerations. Security is tied to trade and investment. If the United States is to continue to provide a significant proportion of the former, the region must open itself even more to the latter.

\section{NOTES}

This article was originally prepared for the SEAS Northeast Asia Symposium sponsored by the American Embassy/USIS, the Japanese Ministry of Foreign Affairs, CINCPAC and the Japan Institute of International Affairs, Tokyo, May 15-17, 1996. Research for the study was partially based on a grant from the U.S. Institute of Peace administered through the National Bureau of Asian Research (Seattle, Washington).

1. Robert Manning and Paula Stern, "The Myth of the Pacific Community," Foreign Affairs, $(73,6)$ November-December 1994, p. 81.

2. Ibid., p. 82.

3. Stuart Harris, "Policy Networks and Economic Cooperation: Policy Considerations in the Asia-Pacific," The Pacific Review, vol. 7, no. 4 (1994), pp. 392-393; see also Kamishka Jayasuriya, "Singapore: The Politics of Regional Definition," Ibid., p. 415.

4. For recent views of this post-cold war concert approach to security, see Pauline Kerr, "The Security Dialogue in the Asia-Pacific," The Pacific Review, vol. 7, no. 4 (1994), pp. 397410; Sheldon Simon, "Realism and Neoliberalism: International Relations Theory and Southeast Asian Security," The Pacific Review, vol 8, no. 1 (1995); and by the same author, "East Asian Security: The Playing Field Has Changed," Asian Survey, vol. 24, no. 12 (December 1994), pp. 1047-1063; and "The ASEAN Regional Forum", in David G. Wiencek and William M. Carpenter, eds., Asian Security Survey: An Assessment of Political-Security Issues in the Asia-Pacific (Armonk, New York: M.E. Sharpe, forthcoming 1996).

5. The following discussion draws particularly from Richard Haass, "Paradigm Lost," Foreign 
Affairs, vol. 74, no. 1 (January/February 1995), pp.45-55; and Tony Smith, The United States and the World-Wide Struggle for Democracy in the Twentieth Century (Princeton: Princeton University Press, 1994).

6. See the article by former Japan Defense Agency vice-minister, Seiki Nishihiro in Ronza (Tokyo), June 1995, in FBIS, Daily Report-East Asia, June 1, 1995, p. 7. Also see the remarks by Assistant Secretary of Defense Joseph S. Nye, Jr. at the Foreign Correspondents' Club of Japan, September 4, 1995.

7. Author's interviews with Asia-Pacific research specialists throughout the region-OctoberNovember 1995.

8. Wang Jisi, "Pragmatic Nationalism: China Seeks a New Role in World Affairs," The Oxford International Review (Winter 1994), p. 30.

9. Seth Faison, "Beijing Sees U.S. Moves as Plot to Thwart China," New York Times, August $1,1995$.

10. Luo Renshi, "Progress and Further Efforts to be Made in Establishing Confidence-Building," International Strategic Studies, no. 2, (Beijing), 1995. p. 24.

11. The White Paper was carried by Xinhua in English, November 16, 1995, in FBIS, Daily Report-China, November 16, 1995, pp. 20-31.

12. Interview with an ROC specialist at the Atlantic Council, Washington, DC, September 26, 1995.

13. Interview with Chu Shulong, deputy director of the North American Department of the China Institute of Contemporary International Relations, Beijing, October 4, 1995.

14. Interview with several specialists at the Institute of International Relations of National Chengchi University, Taipei, October 20, 1995.

15. Interview with Tien Heng-mao, director of the Institute of National Policy Research for the Chang Yung-fa Foundation, Taipei, October 21, 1995.

16. South China Morning Post (Hong Kong), November 28, 1995, in FBIS Daily ReportChina, November 29, 1995, pp. 92-93.

17. Kyodo, December 19, 1995, in FBIS, Daily Report-China, December 20, 1995, p. 7.

18. See Kenneth Pyle's chapter, "Japan's Emerging Strategy in Asia," in Sheldon Simon and Richard Ellings, eds., Security Challenges in Southeast Asia: Enduring Issues, New Structures (Armonk: New York, M.E.. Sharpe, forthcoming 1996); also, author's interview with Ji Guoxing, director, The Shanghai Institute of International Studies, April 14, 1995.

19. This scenario is described by Hisahiko Okazaki in Sapio (Tokyo) in Japanese, December 6 , 1995, in FBIS, Daily Report-East Asia, December 6, 1995, p. 7. Also see Chalmers Johnson, "The Okinawa Rape Incident and the End of the Cold War in East Asia" (San Diego: Japan Policy Research Institute Working Paper, No. 16. February 1996); and Nicholas Kristof, "Japan to Cut Own Military, Keeping G.I.s," The New York Times, November 29, 1995.

20. Kyodo, November 27, 1995, in FBIS, Daily Report-East Asia, November 27, 1995, p. 5.

21. The Japanese polling results are discussed in Takekiko Kama, "US. Japan Security Cooperation in the Asia-Pacific," a paper presented to the International Studies Association, Washington, DC, March 29-April 2, 1994. pp. 16-17.

22. Kenneth Pyle, "Japan's Emerging Strategy in Asia," in Simon and Ellings, op. cit.

23. This analysis is drawn from an interview at Arizona State University with Yung-hwan Jo, former executive director of the Kim Dae-Jung Institute, currently at Sogung University, July 3, 1995.

24. Selig Harrison, "The Korea Divide," The New York Times, April 11, 1996.

25. Vadim Tkachenko, director of the Korean Studies Center of the Far East Affairs Institute of Russia, in FBIS, Daily Report-East Asia, March 8, 1996, p. 30.

26. Interview with Russian Ambassador to the ROK Georgiy Kunadze in Sisa Journal (Seoul), May 30, 1996, as carried by FBIS, Daily Report-East Asia, May 28, 1996, p. 63.

27. Brian Job, Multilateralism: The Relevance of the Concept to Regional Conflict Management (Vancouver: Institute of International Relations, University of British Columbia, Working Paper No. 5, 1994).

28. An excellent discussion of these constraints in Northeast Asia may be found in Taeho Kim, "Old Issues and New Uncertainties: Korean Security in Post-Cold War Northeast Asia," American Defense Annual, 1996 (forthcoming). 
29. See the discussion in Edward Laurence, "Promoting CBMs on the Korean Peninsula: The Role of Building Institutions," (Monterey: Monterey Institute of International Studies, November 1995).

30. The informal North Korean reaction to the CSCAP invitation is mentioned in Ralph Cossa, "Track II and Northeast Asia Security," a paper prepared for the National Strategies in the Asia-Pacific conference, Monterey Institute of International Studies, Monterey, Califomia, March 28-29, 1996, p. 13.

31. Interview with Ji Guoxing, director of the Shanghai Institute of International Studies, at the University of California, San Diego, April 14, 1995.

32. Interviews with Chu Shulong and Yang Jiemian in China.

33. Minutes of the USCSCAP Board of Directors Meeting, Washington, DC, October 20, 1995.

34. See a number of suggestions in CSCAP, Asia Pacific Confidence and Security Building Measures (Memorandum No. 2, 1995) passim.

35. Akio Watanabe and Tsutoma Kikuchi, "Japan's Perspective on APEC: Community or Association?" NBR Analysis, vol 6, no. 3 (November 1995), pp. 29-30. 